\title{
TAXONOMIC ACCOUNT OF ORB-WEAVING SPIDER GENUS Cyrtarachne Thorell, 1868 (ARANEAE: ARANEIDAE) OF BANGLADESH
}

\author{
Biswas, V. and D. Raychaudhuri ${ }^{1}$ \\ Department of Zoology, Khulna Govt. Womens' College, Khulna-9000, Bangladesh; ${ }^{1}$ Department of \\ Agricultural Biotechnology, IRDM Faculty Centre, R.K. Mission Vivekananda University, Narendrapur \\ Kolkata-700103, India
}

\begin{abstract}
A taxonomic study on some orb-weaving spiders of the genus Cyrtarachne Thorell, 1868 (Araneae: Araneidae) were carried out from different areas of Bangladesh. Two species were identified in this study namely $C$. biswajiti n. sp. and $C$. sundari Tikader. $C$. biswajiti has described as new to science. Illustrated descriptions of the species were provided herewith.
\end{abstract}

Key words: Taxonomy; Orb-weaving spider; Cyrtarachne; Araneae; Araneidae; Bangladesh.

\section{INTRODUCTION}

Orb-weaving spiders are peculiar and attractive members due to their colour, body- form, orbweaving behaviour and different types of webs. They also play a great role in controlling insect pests entangling with these webs in the crop-fields and gardens. Members of the genus Cyrtarachne Thorell are typical in shape. They build small webs within plants on which they stay long times for the prey (Biswas et al. 1995). The genus was first established by Thorell in 1868 with the type-species $C$. grubei (Keyserling 1864). Under the genus 55 species are recorded in the world fauna (World Spider Catalog 2019) and 35 species are described on this genus in India and other Asian countries (Tikader 1960, Tikader 1982, Namkung and Kim 1985, Yaginuma 1986, Barrion and Litsinger 1995, Koh 1989, Chen and Zhang 1991, Yin et al. 1997, Zhao 1993, Song et al. 1999, Namkung 2003, Tanikawa 2007, Keswani et al. 2012). In Bangladesh, the genus contains only one species $C$. bengalensis Tikader (Chowdhury and Nagari 1981, Chowdhury and Pal 1984, Okuma et al. 1993, Begum and Biswas 1997, Biswas 2009). The present paper contains only two species namely- C. biswajiti n. sp. and C. sundari Tikader of which C. biswajiti n. sp. is described as new to science.

\section{Collection and Preservation}

\section{MATERIAL AND METHODS}

The study was initiated with the collection of specimens from different areas of Bangladesh. The spiders were collected by hand from the webs and by shaking the branches of trees on an inverted umbrella placed underneath the bushes and trees. The collected specimens were anesthetized using chloroform and were then transferred to a Petridish filled with $70 \%$ ethanol for sorting. After sorting, all the specimens were preserved primarily in $70 \%$ ethanol and after identification the specimens were finally preserved in Audmans' preservatives (90 parts $70 \%$ ethanol +5 parts glacial acetic acid +5 parts glycerine) following Lincoln and Sheals (1985) and Tikader (1987).

\section{Identification and Deposition}

The preserved specimens were identified consulting the following literatures: Kaston (1972), Tikader (1982, 1987), Yaginuma (1986), Davies (1988), Chen and Zhang (1991), Barrion and Litsinger (1995), Yin et al. (1997), Song et al.(1999) and Sen et al. (2015). The preserved specimens are at present in the collection of the Department of Zoology, Khulna Govt. Womens' College, Khulna, 
Bangladesh and will be deposited to the Museum of the Department of Zoology, University of Dhaka, Bangladesh, in due course of time.

\title{
Illustration
}

All the necessary body-parts were dissected out and illustrated under Stereozoom binocular microscope fitted with Camera Lucida. Epigynum is dissected and cleared in $10 \% \mathrm{KOH}$ as mentioned in Tikader (1987). Leg measurements are given in the following sequence: femur, patella, tibia, metatarsus, tarsus and total length. All measurements are taken in millimetres ( $\mathrm{mm})$.

\section{RESULTS AND DISCUSSION}

\author{
Taxonomy \\ Family: ARANEIDAE Latreille, 1806 \\ Genus: Cyrtarachne Thorell, 1868 \\ Type-species: C. grubei (Keyserling)
}

1868. Cyrtarachne Thorell, Eng. Resa, Aracha. : 10.

1878. Dema: Karsch, Z. ges. Naturw. 51: 801.

1895. Cyrtarachne: Simon, Hist. Nat. Araign, 1(4): 880.

1900. Cyrtarachne: Pocock, Fauna of Brit. India, Archn. : 228.

1960. Cyrtarachne: Yaginuma, Spiders of Japan in colour: 61.

1960. Cyrtarachne: Tikader, J. Bombay nat. Hist. Soc., 57(3): 547.

1982. Cyrtarachne: Tikader, Fauna of India, Araneidae, 2(1): 138.

1986. Cyrtarachne: Yaginuma, Spiders of Japan in color,: 109.

1988. Cyrtarachne: Davies, Mem. Qld. Mus., 25(2): 38.

1995. Cyrtarachne: Barrion \& Litsinger, Riceland spiders of South and Southeast Asia,: 581.

1997. Cyrtarachne: Platnick, Adv. Spider Taxonomy, : 498.

1997. Cyrtarachne: Yin, et al., Fauna Sinica, Araneidae,: 267.

1999. Cyrtarachne: Song, et al., The spiders of China,: 272.

2005. Cyrtarachne: Majumder, Mem. Zool. Surv. India, 20(3): 9.

2009. Cyrtarachne: Biswas: In Ahmed (ed.), Flora \& Fauna of Bangladesh, 18(1): 149.

2015. Cyrtarachne : Platnick, World Spider Catalog, Version 15.0, http://www.research.amnh.org/iz/spider/catalog/intro.html

2019. Cyrtarachne : World Spider Catalog, Version 19.5, Natural History Museum, Bern. http://www.wsc.nmbe.ch

[All synonyms and references are listed in the world Spider Catalog, 2019]

\section{Diagnosis}

Body small, nearly rounded. Cephalothorax dorsally strongly convex and wider than long and unnamed. Eyes small; lateral eyes large and contiguous. Chelicerae small, thick; inner and outer margins with small teeth. Maxillae and labium leathery, scpulate. Legs long and slender; tibia 1 and 2 with strong spines. Abdomen triangular or rhomboid or elongately oval, with or without humps, leathery and with or without sigilla; epigyne variable in shape.

\section{Biological note}

Spiders of this genus are commonly known as 'Orb-weavers'. Most of them usually construct typical orb-webs and stay on or at the side of this. They quietly stay for the prey and are one of the important biological control agents of insect pests in the crop-fields and gardens. 
Distribution: Africa; Asia; Australia

\section{Description of the species of Cyrtarachne Thorell, 1806}

\section{Material examined}

1. Cyrtarachne sundari Tikader (Fig. 1, Fig. 3a)

1female, Bagerhat, 18 .V. 1992, Coll. V. Biswas; 1 female, S. Park, Dhaka, 03. III. 1993, Coll. V. Biswas; 1 female, Tea Estate, Japhlong, Sylhet, 28. XII. 1993, Coll. V. Biswas; 2 female, Mymensing, 18. V. 1993, Coll. V. Biswas.

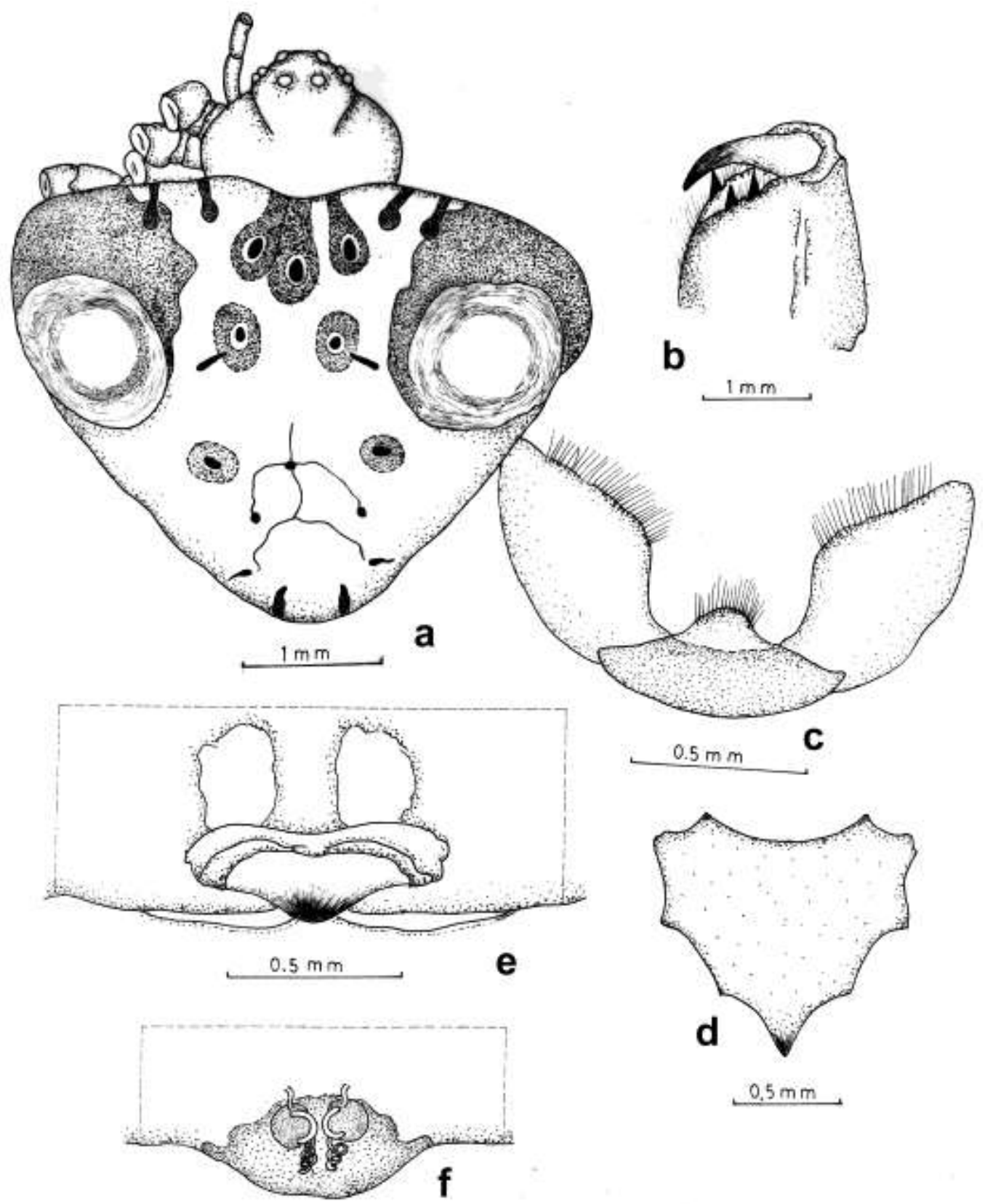

Fig. 1. Cyrtarachne sundari Tikader: a. Whole body (dorsal view); b. Chelicerae; c. Maxillae and Labium; d. Sternum; e. Epigynum; f. Internal genitalia. 


\section{Description of the female}

Body size medium. Cephalothorax and legs brown; abdomen yellow-brown. Total body length 10 $\mathrm{mm}$. Carapace $3.50 \mathrm{~mm}$ long, $3.80 \mathrm{~mm}$ wide; abdomen $6.50 \mathrm{~mm}$ long and $6.50 \mathrm{~mm}$ wide. ( Fig. 1a )

\section{Cephalothorax}

Wider than long, nearly triangular, with fine hairs; cephalic region raised, anteriorly produced, cervical furrows distinct. Eyes yellowish, laterals small and close; anterior row recurved and posterior row faintly procurved; ocular quad squarish, faintly narrowing posteriorly. Chelicerae brown and strong, each of inner and outer margins with 2 and 1 teeth (Fig. 1b). Maxillae brownish, dagger-shaped, medially wide, scopulate anteriorly (Fig. 1c). Labium brown, roughly triangular, anteriorly produced and scopulate (Fig. 1c). Sternum brown, somewhat t-shaped, posteriorly pointed (Fig. 1d). Legs short, slender, moderately strong, clothed with spines and hairs; femur 1 provided with 2 tubercles on trilateral surface ; leg formula 1423 and the measurements (in $\mathrm{mm}$ ) are shown in Table 1.

Table 1. Measurements (in mm) of leg segments of Cyrtarachne sundari Tikader.

\begin{tabular}{lcccccc}
\hline Leg & Femur & Patella & Tibia & Metatarsus & Tarsus & Total \\
\hline I & $2.00 / 2.00$ & $1.00 / 1.00$ & $2.00 / 2.00$ & $1.50 / 1.50$ & $0.60 / 0.60$ & $7.10 / 7.10$ \\
II & $2.80 / 2.80$ & $0.50 / 0.50$ & $2.00 / 2.00$ & $1.00 / 1.00$ & $0.60 / 0.60$ & $6.90 / 6.90$ \\
III & $1.80 / 1.80$ & $0.50 / 0.50$ & $1.20 / 1.20$ & $0.90 / 0.90$ & $0.30 / 0.30$ & $4.80 / 4.80$ \\
IV & $2.50 / 2.50$ & $1.00 / 1.00$ & $2.00 / 2.00$ & $1.00 / 1.00$ & $0.50 / 0.50$ & $7.00 / 7.00$ \\
\hline
\end{tabular}

\section{Abdomen}

Triangular, massive, extremely wider than long, convex, strongly overlapping the carapace; dorsum with 2 shoulder humps, brown sigilla and brownish and yellowish patches and markings; ventrally with large, black patch from epigastric furrow up to the spinnerets; epigyne and internal genitalia as in figs. 1e-f.

Distribution: Bangladesh (Biswas 2009), India (Tikader 1963, 1982).

\section{Cyrtarachne biswajiti n. sp. (Fig. 2, Fig. 3b)}

\section{Material examined}

Holotype: 1 female, Pirojpur, 19. IX. 1991, Coll. V. Biswas. Paratypes: 2 females, Potuakhali and Faridpur, 12.X.1991 and 14. X. 1992, Coll. V. Biswas.

\section{Description of the female}

Body small in size. Cephalothorax greenish-yellow; legs brownish-yellow; abdomen pale yellow with dorsal silvery scale. Total body length $10.10 \mathrm{~mm}$. Carapace $4.10 \mathrm{~mm}$ long, $2.00 \mathrm{~mm}$ wide; abdomen $5.00 \mathrm{~mm}$ long and $6.20 \mathrm{~mm}$ wide (Fig. 2a).

\section{Cephalothorax}

Wider than long, basally wide, narrowing anteriorly, centrally with a small fovea; cephalic region raised with distinct, cervical furrows; radii distinct. Eyes brownish, ringed with black bands, posteromedians larger; anterior row recurved and posterior row nearly straight; lateral eyes close; ocular quad wider than long. Chelicerae brown, thick, each of inner and outer margins with 3 and 4 teeth (Fig. 2b). Maxillae brown, longer than wide, anteriorly wide and scopulate (Fig. 2c). Labium pot-like, wider than long, anteriorly narrowing and scopulate (Fig. 2c). Sternum brownish, longer than wide, anterior margin straight, posteriorly bluntly pointed, clothed with small spines and hairs (Fig. 2d). Legs long and slender, clothed with spines and hairs; leg formula 1243 and the measurements (in mm) (Table 2). 
Table 2. Measurements (in mm) of leg segments of Cyrtarachne biswajiti n. sp.

\begin{tabular}{lcccccc}
\hline Leg & Femur & Patella & Tibia & Metatarsus & Tarsus & Total \\
\hline I & $4.00 / 4.00$ & $1.00 / 1.00$ & $2.00 / 2.00$ & $2.00 / 2.00$ & $1.20 / 1.20$ & $10.20 / 10.20$ \\
II & $3.80 / 3.80$ & $1.00 / 1.00$ & $2.00 / 2.00$ & $1.80 / 1.80$ & $1.10 / 1.10$ & $9.70 / 9.70$ \\
III & $2.00 / 2.00$ & $0.50 / 0.50$ & $1.00 / 1.00$ & $0.90 / 0.90$ & $0.50 / 0.50$ & $5.90 / 5.90$ \\
IV & $3.40 / 3.40$ & $1.00 / 1.00$ & $1.20 / 1.20$ & $0.90 / 0.9$ & $0.60 / 0.60$ & $7.10 / 7.10$ \\
\hline
\end{tabular}
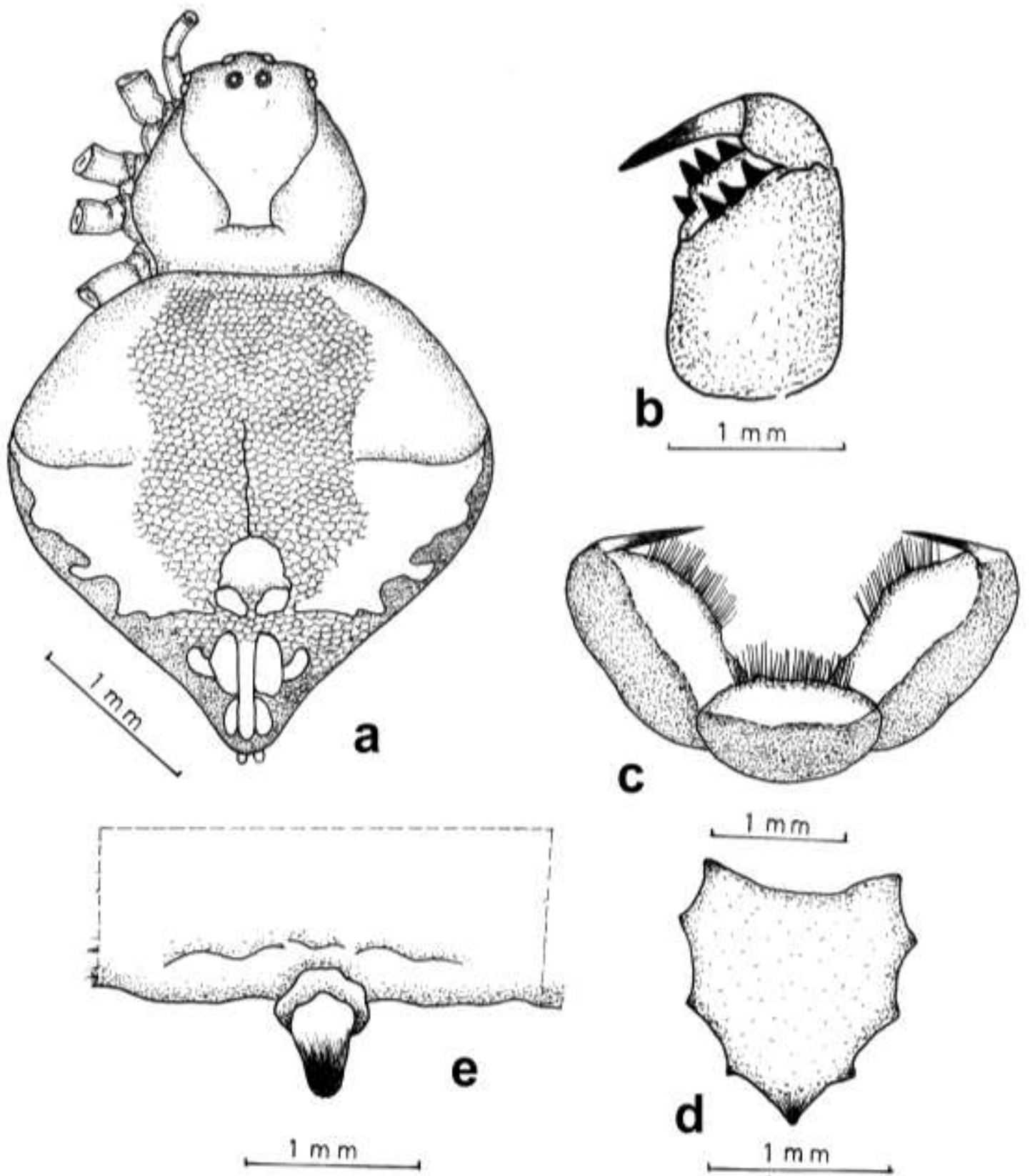

Fig. 2. Cyrtarachne biswajiti n. sp.: a. Whole body (dorsal view); b. Chelicerae; c. Maxillae and Labium; d. Sternum ; e. Epigynum.

\section{Abdomen}

Broad, rhomboid, medially wide, posteriorly narrowed with bluntly pointed tip; dorsum decorated; epigynum as in Fig. 2e. 


\section{Male unknown.}

Type-locality: Pirojpur, Potuakhali and Faridpur.

Etymology: The species is named after the name of my beloved brother Biswajit Biswas who constantly assisted in the collection.
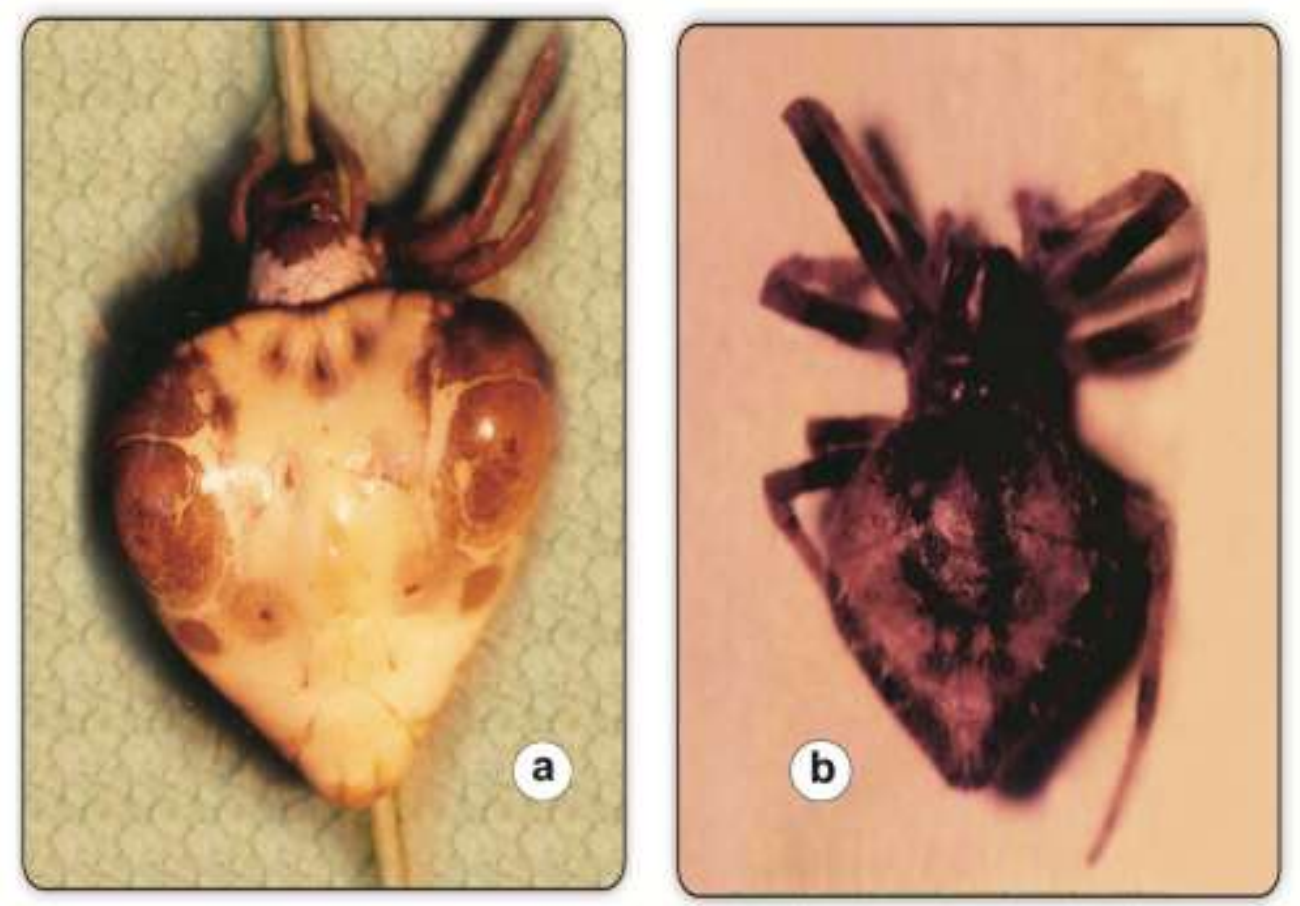

Fig. 3. Pictorial view of described species (dorsal view): a. Cyrtarachne sundari Tikader; b. Cyrtarachne biswajiti n. sp.

\section{Remarks}

None of the congeneric species (Tikader 1982, Yaginuma 1986, Koh 1989, Namkung and Kim 1985 , Yin et al. 1997, Barrion and Litsinger 1995) are known to have abdomen posteriorly tail-like, medially reticulate, epigynal scape tongue-like and in many other aspects well. Although, in external appearance, some dorsal similarities found with $C$. promilai Tikader (Tikader 1982) but it is easily be separated from the present species in having different cephalic and abdominal decoration, tail-like posterior ends of abdomen and different tongue-like epigynum (Fig. 2a, Fig. 2e). The species is therefore described as new to science.

\section{ACKNOWLEDGEMENTS}

The authors are thankful to Dr. S. C. Majumder, Scientist-SD, Zoological Survey of India, Kolkata, for his kind help in the confirmation of the species identity. They also express gratitude to the Principal, Government P. C. College, Bagerhat, Bangladesh, for his kind permission to continue the research.

\section{REFERENCES}

Barrion, A. T. and J. A. Litsinger. 1995. Riceland spiders of South and Southeast Asia. CAB International, Wallingford, UK. 700 pp.

Begum, A. and V. Biswas. 1997. A list of spider fauna of Barisal division, Bangladesh (Araneae: Arachnida ). Bangladesh J. Zool. 25(2): 207-210. 
Biswas, V. 2009. Arachnida. In: Ahmed (eds.). Encyclopedia of flora and fauna of Bangladesh. Vol. 18(1). Asiatic Society of Bangladesh, Dhaka, Bangladesh. 437 pp.

Biawas, V., N. Q. Kamal and A. Begum.1995. Orb-weaving behaviour of some rice-field spiders. Bangladesh J. Zool. 23(2): 147-152.

Chen, Z. F. and Z. H. Zhang. 1991. Fauna of Zhejiang, Araneida. Zhejiang Science and Technology Publishing House, China. 356 pp.

Chowdhury, S. H. and S. Nagari. 1981. Rice-field spiders from Chittagong. Proc. Zool. Soc. Bangladesh : 53-72.

Chowdhury, S. H. and S. K. Pal. 1984. Further report on rice-field spiders from Bangladesh. Chittagong Univ. Stud. Part II. 8(1): 25-39.

Davies, V. T. 1988. Illustrated guide to the genera of orb-weaving spiders of Australia. Mem. Qld. Mus. 25: $273-332$.

Kaston, B. J. 1972. How to know the spiders. The pictured key nature series. Wm. C. Brown Co. Ltd., Dubuque, Iowa, USA. 172 pp.

Keswani, S., P. Hadole and A. Rajoria 2012. Checklist of spiders (Arachnida: Araneae) from India. Indian J. Arachnol. 1(1): 101-129.

Kim, S. T. and S. Y. Lee. 2012. Invertebrate fauna of Korea: Araneid Spiders. Natl. Inst. Biol. Resour. 21(16): 1-146.

Lincoln, R. J. and J. G. Sheals. 1985. Invertebrate Animals: Collection and Preservation. British Museum (Natural History), London, UK. 150 pp.

Namkung, J. 2003. The Spiders of Korea. 2nd ed. Kyo-Hak Publishing Co., Seoul, South Korea. 648 pp.

Namkung, J. and J. P. Kim. 1985. On the unreported species of Cyrtarachne bufo (Boesenberg et Strand, 1906) (Araneidae: Araneae) from Korea. Korean Arachnol. 1(1): 23-25.

Okuma, C., N. Q. Kamal, Y. Hirashima, Z. Alam and T. Ogata. 1993. Illustrated Monograph of the ricefield spiders of Bangladesh. IPSA-JICA, Salna, Gazipur, Bangladesh. 93 pp.

Sen, S., D. C. Dhali, S. Saha and D. Raychaudhuri. 2015. Spiders (Araneae : Arachnida ) of reserve forests of Dooars, Gorumara National Park, Chapramari Wildlife Sanctuary and Mahananda Wildlife Sanctuary. World Scientific News. 20: 1-339.

Song, D. X., M. S. Zhu and J. Chen. 1999. The Spiders of China. Hebei University of Science and Technology Publishing House, Shijiazhuang, China. 640 pp.

Tanikawa, A. 2007. An Identification Guide to the Japanese Spiders of the families Araneidae, Nephilidae and Tetragnathidae. Arachnological Society of Japan, Osaka, Japan. 121 pp.

Tikader, B. K. 1960. Revision of Indian spiders of the genus Cyrtarachne (Argiopidae: Arachnida). $J$. Bombay Nat. Hist. Soc. 57(3): 547-556.

Tikader, B. K. 1963. Further studies on Indian spiders of the genus Cyrtarachne (Family: Argiopidae). Misc. Notes. J. Bombay nat. Hist. Soc. 60(1): 268-276.

Tikader, B. K. 1982. Fauna of India: Spiders (Araneae: Araneidae). 2(1): 1-293.

Tikader, B. K. 1987. Handbook of Indian Spiders. Zoological Survey of India, Kolkata, India. 251 pp. 
Yaginuma, T. 1986. Spiders of Japan in colour. 2nd ed. Hoikusha Publishing Co. Ltd., Osaka, Japan. $305 \mathrm{pp}$.

Yin, C. M., J. F. Wang, M. S. Zhu, L. P. Xie, X. J. Peng and Y. H. Bao. 1997. Fauna Sinica: Arachnida: Araneae: Araneidae. Science Press, Beijing, China. 460 pp.

Zhao, J. Z. 1993. Spiders in the cotton fields in China. Wuhan Publishing House, Wuhan, China. 552 pp. 